\title{
Evolution of various salt concentrations in the moisture and in the outer layer and centre of a model cheese during its brining and storage in an ammoniacal atmosphere
}

\author{
Frédéric Gaucheron*, Yvon Le Graët, Françoise Michel, \\ Valérie Briard, Michel Piot
}

Laboratoire de recherches de technologie laitière, Inra, 65 rue de Saint Brieuc, 35042 Rennes cedex, France

(Received 8 July 1998; accepted 20 May 1999)

\begin{abstract}
The evolution of various salt concentrations in moisture and in the outer layer and centre of a model cheese during brining and storage in an ammoniacal atmosphere was studied. During brining, calcium, magnesium, potassium, inorganic phosphate and citrate ions entered the brine with a slight decrease in their contents in the moisture. In parallel, sodium and chloride were incorporated in outer layer and in the moisture of gel. Then, during storage of this model gel in an ammoniacal atmosphere, calcium, magnesium, inorganic phosphate and citrate ions migrated to the outer layer of gel and consequently underwent a decrease in their concentrations in the moisture and the centre of the gel. These migrations are related to the formation of $\mathrm{pH}$ gradient in the gel which induce precipitations of these ions in the outer layer. In parallel, sodium, potassium and chloride were rapidly present uniformly in the different parts of the gel. The model cheese potentialities are also discussed. (C) Inra/Elsevier, Paris.
\end{abstract}

model cheese / minerals / aqueous phase / pH / salt / brining / ripening

Résumé - Évolution des concentrations minérales dans la phase aqueuse, la partie centrale et la surface d'un fromage modèle durant son saumurage et son stockage en atmosphère ammoniacale. Durant le saumurage, les ions calcium, magnésium, potassium, phosphate inorganique et citrate passent dans la saumure avec une légère diminution de leurs concentrations dans la phase aqueuse. En parallèle, les ions sodium et chlorure sont incorporés à la surface et dans la phase aqueuse du gel. Puis, durant le stockage en ambiance ammoniacale, les ions calcium, magnésium, phosphate inorganique et citrate migrent vers la surface du gel avec comme conséquence une diminution de leurs concentrations dans la phase aqueuse et dans la partie centrale du gel. Ces migrations sont dues à la

* Correspondence and reprints. fgaucher@labtechno.roazhon.inra.fr 
formation d'un gradient de $\mathrm{pH}$ dans le gel qui entraîne une précipitation de ces ions en surface. En parallèle, les ions sodium, potassium et chlorure étaient rapidement répartis de façon uniforme dans les différentes parties du gel. Les potentialités de ce fromage modèle sont également discutées. (C) Inra/ Elsevier, Paris.

\section{fromage modèle / minéraux / phase aqueuse / $\mathrm{pH}$ / saumurage / affinage}

\section{INTRODUCTION}

Cheese is composed of a paracaseinic network, dispersed elements (cells, fat globules, crystals and air) and interstitial liquid containing several dissolved compounds (proteins, sugar, lipids and minerals). During its fabrication, physicochemical composition of cheese varies as a function of acidification, brining, alcalinisation, proteolysis and lipolysis. Proteolysis and amino acid catabolism, lipolysis and lactose breakdown are relatively well described in the literature $[4-6,11,32]$. On the contrary, much less is known about the salt fraction evolution during brining and ripening although this fraction plays a considerable role in the texture elaboration and in the rheological properties of cheese $[6,16,23,24$, $28,31,32]$. Moreover, some of these modifications are sequential and others can take place at the same time. So, for simultaneous modifications, it is difficult to understand the fundamental phenomena.

The objective of this work was to develop a model gel to study the salt behaviour during brining and storage under ammoniacal atmosphere; model gel was chosen to limit the numerous other changes that occur during brining and ripening of cheese, i.e. lactose degradation, proteolysis and lipolysis. Two approaches were used. The first one was the determination of salt contents in the moisture obtained by gel pressing $[22,27]$, after brining and as a function of time of storage in ammoniacal atmosphere. It is noteworthy that most of the few studies related to the characterization of the moisture extracted from cheese concern hard cheeses
$[22,27]$. The second approach was the direct determination of the total mineral content in the outer layer and in the centre of the gel before and after brining and as a function of storage time.

\section{MATERIALS AND METHODS}

\subsection{Experimental protocol}

The experimental protocol is schematically presented in figure 1. This protocol and subsequent analyses were carried out in triplicate.

\subsection{Milk epuration by cross-flow microfiltration}

Raw skim milk from Triballat (Noyal-surVilaine, France) was used. Before microfiltration, the skim milk was preheated to $50^{\circ} \mathrm{C}$. Then, cross-flow microfiltration was used to eliminate bacteria [30]. The membrane module in alumine Sterilox (Société des céramiques techniques, Tarbes, France) had 19 channels, each with an inner diameter of $4 \mathrm{~mm}$, and a total membrane area of $0.2 \mathrm{~m}^{2}$. The average nominal pore size was $1.4 \mu \mathrm{m}$. The temperature was $50^{\circ} \mathrm{C}$. Under these conditions almost all of the whey proteins and casein micelles pass through the membrane while $99.99 \%$ of bacteria are retained [30]. The permeate was then concentrated by ultrafiltration (UF).

\subsection{Ultrafiltration}

The preparation of the UF retentate was carried out as previously described by Maubois \& Mocquot [20]. The membrane M1 (Carbosep ${ }^{(1)}$, Orelis, France) was used (molecular mass cutoff: $\left.150000 \mathrm{~g} \cdot \mathrm{mol}^{-1}\right)$ at $50^{\circ} \mathrm{C}$. Under these con- 


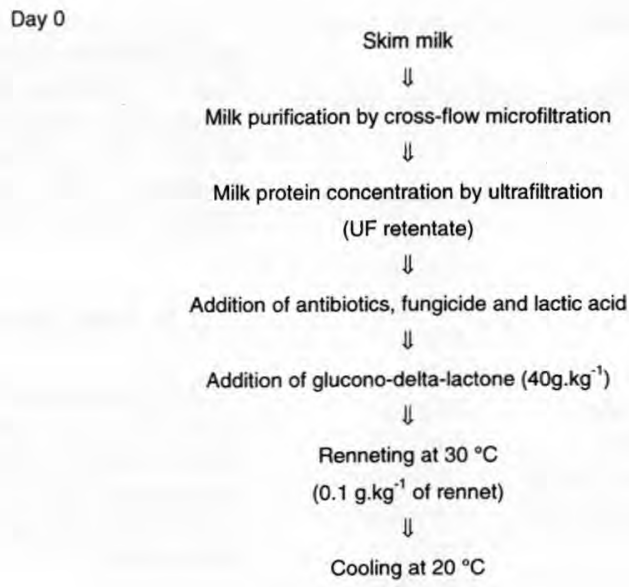

Figure 1. Protocole expérimental pour la préparation de fromage modèle.

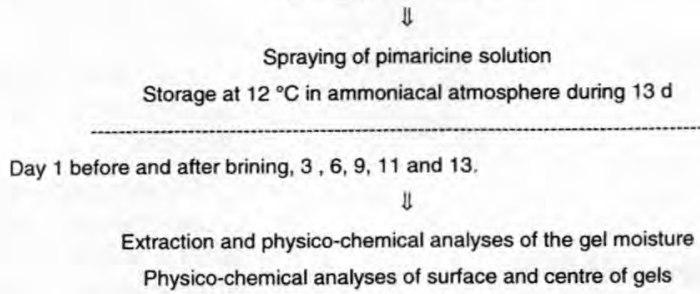

ditions, whey proteins can pass slightly through the membrane (rejection of $75 \%$ ) while casein micelles are retained. To limit bacterial growth and contamination, nisin, penicillin $\mathrm{G}$ and streptomycin (Sigma, MO, Saint-Louis, USA) were added to the UF retentate at the following final concentrations: $100 \mathrm{UI} \mathrm{mL}^{-1}, 12 \mathrm{UI} \mathrm{mL}^{-1}$ and $12 \mathrm{mg} \cdot \mathrm{L}^{-1}$ [17]. A final concentration of $10^{-4} \mathrm{~mol} \cdot \mathrm{L}^{-1}$ of $\varepsilon$ amino caproic acid was added to inhibit residual plasmin activity. The protein concentration was about $210 \mathrm{~g} \cdot \mathrm{kg}^{-1}$.

\subsection{Acidification and renneting}

A lactic acid (Sigma, France) solution ( $1 \mathrm{~mol} \cdot \mathrm{L}^{-1}$ dissolved in UF permeate) was added under stirring to the UF retentate to have a $\mathrm{pH}$ value of about 6.3. A glucono-delta-lactone (GDL) (Lysactone, Roquette, Lestrem, France) concentration of $40 \mathrm{~g} \cdot \mathrm{kg}^{-1}$ was added to the UF retentate previously incubated at $30^{\circ} \mathrm{C}$ to have $\mathrm{pH}$ value of about 4.75 after $24 \mathrm{~h}$. Immediately after GDL addition, $0.10 \mathrm{~g} \cdot \mathrm{kg}^{-1}$ of rennet solution (1/10 000) (laboratoire Granday-Roger, Beaune, France) was added to the UF retentate. The rennet coagulation time was about $20 \mathrm{~min}$. The gels obtained were left standing overnight at room temperature. The rate of cooling to $20^{\circ} \mathrm{C}$ after gel formation was less than one hour. Afterwards, a slight syneresis, with a loss of about $20 \mathrm{~g}$ for a total weight of $370 \mathrm{~g}$ of gel, was observed. The characteristics of the model gel are indicated in table I.

\subsection{Brining}

A saturated brine $\left(330 \mathrm{~g} \cdot \mathrm{kg}^{-1}\right.$ of $\left.\mathrm{NaCl}\right)$ was prepared from distilled water and dairy salt (Compagnie saline du midi, Dax, France). The conditions of the brining were $30 \mathrm{~min}$ at $12^{\circ} \mathrm{C}$ with a ratio of $2 \mathrm{~L}$ of brine per gel. Brining was done under manual stirring to maintain the brine concentration constant throughout the experiment. 
Table I. Characteristics of the model cheese before brining.

Tableau I. Caractéristiques du fromage modèle avant saumurage.

\begin{tabular}{ll}
\hline Diameter & $11.0 \mathrm{~cm}$ \\
Height & $3.7 \mathrm{~cm}$ \\
Surface & $318 \mathrm{~cm}^{2}$ \\
Volume & $351 \mathrm{~cm}^{3}$ \\
Weight & $370 \mathrm{~g}$ \\
PH & 4.75 \\
Glucono-Delta-Lactone & $40 \mathrm{~g} \cdot \mathrm{kg}^{-1}$ \\
Total Nitrogen X 6.38 & $208 \mathrm{~g} \cdot \mathrm{kg}^{-1}$ \\
Non Casein Nitrogen X 6.38 & $28.9 \mathrm{~g} \cdot \mathrm{kg}^{-1}$ \\
Non Protein Nitrogen X 6.38 & $4.8 \mathrm{~g} \cdot \mathrm{kg}^{-1}$ \\
Fat & $0 \mathrm{~g} \cdot \mathrm{kg}^{-1}$ \\
Lactose & $39 \mathrm{~g} \cdot \mathrm{kg}^{-1}$ \\
Calcium & $5.700 \mathrm{~g} \cdot \mathrm{kg}^{-1}$ \\
Magnesium & $0.300 \mathrm{~g} \cdot \mathrm{kg}^{-1}$ \\
Sodium & $0.450 \mathrm{~g} \cdot \mathrm{kg}^{-1}$ \\
Potassium & $1.740 \mathrm{~g} \cdot \mathrm{kg}^{-1}$ \\
Chloride & $0.800 \mathrm{~g} \cdot \mathrm{kg}^{-1}$ \\
Inorganic phosphate & $6.700 \mathrm{~g} \cdot \mathrm{kg}^{-1}$ \\
Citrate & $1.950 \mathrm{~g} \cdot \mathrm{kg}^{-1}$ \\
Dry matter & $29.23 \%$
\end{tabular}

\subsection{Storage conditions}

The gels obtained were sprayed with a $5 \mathrm{~g} \cdot \mathrm{L}^{-1}$ pimaricine solution (Delvocid ${ }^{\circledR}$, Gist-brocades, Seclin, France) and stored in an ammoniacal atmosphere for 13 days. Storage in ammoniacal atmosphere was necessary to create a $\mathrm{pH}$ gradient in the model gel. The $\mathrm{NH}_{3}$ diffusion was done from a vessel containing $2 \mathrm{~mol} \cdot \mathrm{L}^{-1}$ (day 1 ) and then $0.3 \mathrm{~mol} \cdot \mathrm{L}^{-1}$ (day 2 to day 13 ) ammoniacal solution in a ripening box (volume $0.75 \mathrm{~m}^{3}$ ). Temperature and relative humidity were $12{ }^{\circ} \mathrm{C}$ and $95 \%$, respectively.

\subsection{Moisture extraction}

The extraction protocol used was the one described by Salvat-Brunaud et al. [27] for cooked hard cheese of the Emmental type and adapted to soft cheese by Pierre et al. [26]. The methodology of this extraction has the advantages of preserving the mineral equilibrium and obtaining sufficient quantities of moisture for physicochemical analyses without use of chemical compounds or dilution. The quantity of gel was $1.2 \mathrm{~kg}$ and the ratio sand/gel was about 1.2/1.
The extractions of moisture were carried out on day 1 (before and after brining), 3, 6, 9, 11 and 13 (day $0=$ renneting day). Before mineral analyses of moisture, samples were ultrafiltered on Centriflo CF 25 membrane (molecular mass cut-off: $25000 \mathrm{~g} \cdot \mathrm{mol}^{-1}$, Amicon, Epernon, France) $\left(800 \mathrm{~g}, 30 \mathrm{~min}, 12^{\circ} \mathrm{C}\right.$ ).

\subsection{Zone preparation}

The preparations of the outer layer and centre of the gel were carried out on day 1 (before and after brining), $3,6,9,11$ and 13 (day $0=$ renneting day) $[18,19]$. The depth and weight of each zone of the gel were about $2 \mathrm{~mm}$ and $65 \mathrm{~g}$, respectively.

\subsection{Analyses}

The $\mathrm{pH}$ values were measured with a Portamess $\mathrm{pH}$-meter.

The contents in total protein were determined according to the IDF method (standard 20B:1993).

For mineral content determination in different zones of the gel, about $1 \mathrm{~g}$ of gel was homogenised in $30 \mathrm{~g}$ of $0.02 \mathrm{~mol} \cdot \mathrm{L}^{-1}$ nitric acid solution. Then, after standing overnight at room temperature, the solution was filtered on Whatman 42 .

On the filtrates, cation (calcium, magnesium, sodium and potassium) and anion (chloride, phosphate, citrate) concentrations were determined using atomic absorption spectrometry (Varian, Les Ulis, France) [2] and ion chromatography (Dionex, Jouy-en-Josas, France) [7], respectively. The accuracies of the cation and anion determinations were about $\pm 2 \%$. The concentration units were expressed in $\mathrm{mg}$ per $\mathrm{kg}$ of material (moisture or gel).

\subsection{Theoretical calculation of calcium phosphate saturation indexes in a $\mathrm{pH}$ range between 4.8 and 6.5 .}

From initial composition of moisture (day 1 after brining) and with a $\mathrm{NaCl}$ concentration of $4 \mathrm{~mol} \cdot \mathrm{L}^{-1}$, calcium phosphate saturation indexes in a $\mathrm{pH}$ range between 4.8 and 6.5 were calculated. The saturation indexes with respect to a given calcium phosphate phase were defined as the ratio: ionic activity product in solution/solu- 
bility product. Calculations were performed by an iterative method described by Holt et al. [13]. Although calcium is bound more strongly to gluconate than to lactate, we have assimilated both these ions. It is noteworthy that the results of these theoretical calculations indicated tendencies and were of semi-quantitative significance.

\section{RESULTS AND DISCUSSION}

\subsection{Brining effects}

The comparison of results before and after brining on day 1 of model cheese showed that this step has multiple physicochemical effects. Firstly, the sodium and chloride concentrations in the moisture and in the outer layer increased strongly (figures $2 A, 3 A$, respectively). In the centre of the gel, con- centrations of these ions were unaffected, indicating that the diffusions of ionic sodium and chloride were not immediate. Secondly, the $\mathrm{pH}$ (figure $4 A$ ) and the concentrations of calcium (figure 5A), magnesium (figure 6A), potassium (figure $7 A$ ), inorganic phosphate (figure $8 A$ ) and citrate (figure $9 A$ ) in moisture and the outer layer decreased while those of the centre were not modified. The variations in the outer layer of the ratio concentration before brining/concentration after brining expressed in \% were $32,36,45,28$ and $36 \%$ for calcium, magnesium, potassium, inorganic phosphate and citrate, respectively. In parallel, low decreases were observed in the moisture: 9.6, 9.5, 13, 1 and $1.5 \%$ for calcium, magnesium, potassium, inorganic phosphate and citrate, respectively. These differences in variations between the outer
Figure 2. Sodium concentration in the moisture and in two zones of the gel before (white histogram) and after brining (black histogram) (A) and as a function of storage time in ammoniacal atmosphere (B): moisture; $(\mathbf{C})$ : outer layer $(\bullet)$

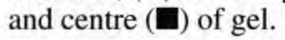

Figure 2. Concentration en sodium de la phase aqueuse et de deux parties du gel avant (histogramme blanc) et après saumurage (histogramme noir) (A) et en fonction du temps de stockage en atmosphère ammoniacale (B): phase aqueuse ; $(\mathbf{C})$ : surface $(\bullet)$ et

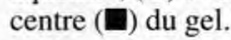
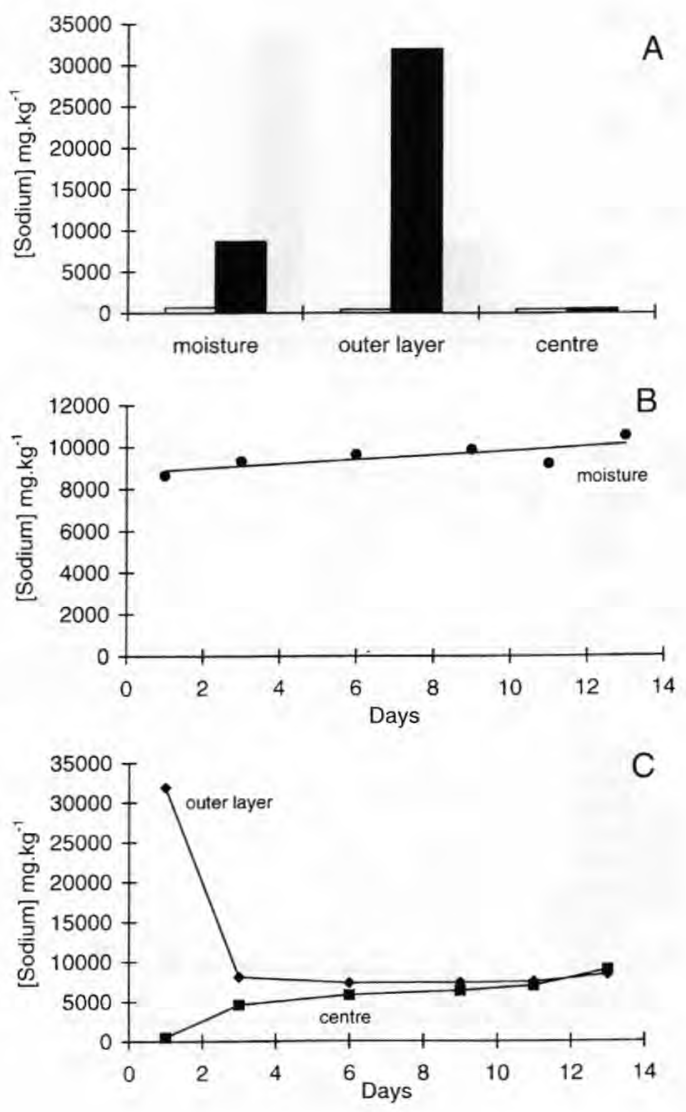
layer and the moisture showed that the salt absorption is essentially a surface phenomenon.

To approximate the diffusion coefficient of $\mathrm{NaCl}$, these results were compared with those obtained on model cheese containing $70 \%$ of moisture [9]. A value close to $0.4 \mathrm{~cm}^{2} / \mathrm{d}$ was found. In previously published works, Geurts et al. $[9,10]$ and Hardy [12] described the salt diffusion respectively, in model cheese and Camembert cheese, as a process derived from Fick's law and determined a diffusion coefficient of about $0.2 \mathrm{~cm}^{2} / \mathrm{d}$. Three reasons can explain these discrepancies between both determinations. Firstly, the technologies to prepare our curds were not those used for traditional cheese. Secondly, our model has a higher moisture content (about $70 \%$ against $55 \%$ in mould- ripened cheeses). Thirdly, fat was absent in our gel.

In parallel to the absorption of salt, these decreases of ion concentration in the outer layer are due to ion transfers by diffusion from the gel surface towards the brine. It is noteworthy that using a freshly made $\mathrm{NaCl}$ solution, rather than used brine, leads to a marked loss of soluble components. Indeed, the mineral transfers during brining were less important when brine was old or when calcium chloride was added to the brine [ 3 , $8,29]$.

The other consequence of brining is a loss of aqueous phase. In our case, no data concerning water loss was determined. However, this well-known phenomenon is described by several authors $[3,8-10,12$, 29, 32]. Geurts et al. [9] and Hardy [12]
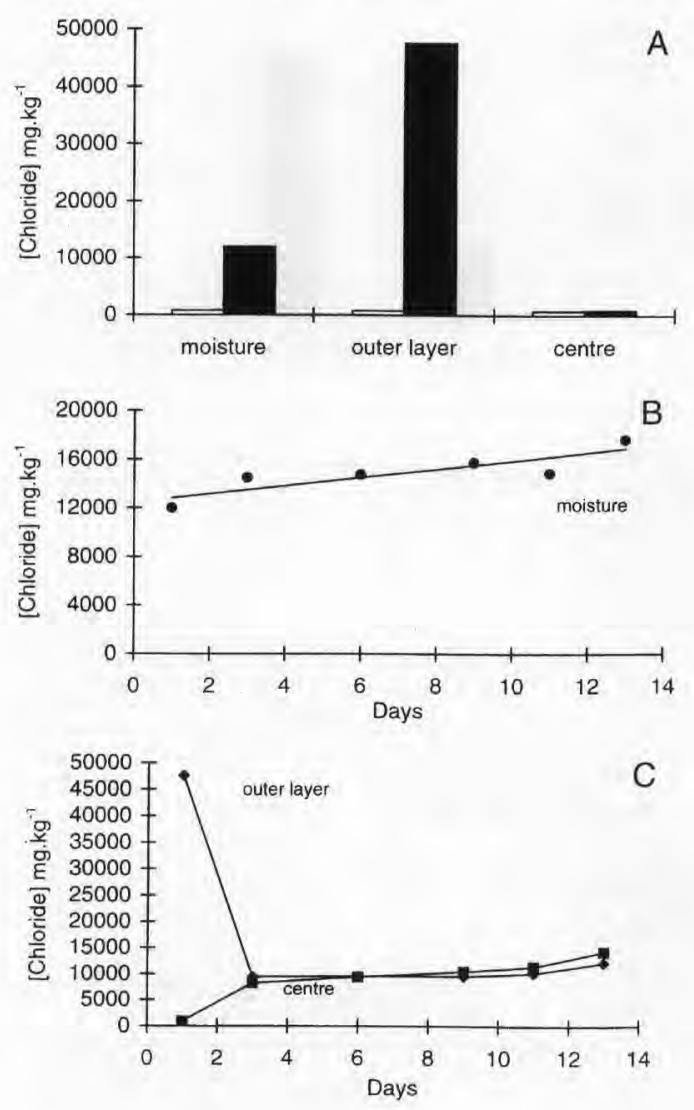

Figure 3. Evolution of chloride concentration. Same symbols as figure 2 .

Figure 3. Évolution de la concentration en chlorure. Mêmes symboles que pour la figure 2. 
found a constant ratio of 2.5 between the absorption of salt and the loss of moisture in a soft cheese. In our case this ratio is probably different because: a) our curds have surfaces different from those of Camembert cheese (table I); b) the chemical composition of our brine (only $\mathrm{NaCl}$ ) was different from those used in cheese making $(\mathrm{NaCl}$, minerals, organic compounds coming from whey) $[3,8]$.

\subsection{Effects of storage in an ammoniacal atmosphere}

\subsubsection{Calcium, magnesium, inorganic phosphate and citrate ions}

In the absence of ammonia, no significant variation of $\mathrm{pH}$ and ion concentrations was observed [results not shown and 18, 19]. Conversely, during storage in an ammoniacal atmosphere, the $\mathrm{pH}$ of the moisture (figure $4 B$ ), in the outer layer and in the centre increased (figure $4 C$ ). The calcium (figure $5 B$ ), magnesium (figure $6 B$ ), inorganic phosphate (figure $8 B$ ) and citrate (figure $9 B$ ) concentrations in the moisture decreased. In parallel, the concentrations of these ions increased in the outer layer and decreased in the gel centre (figure $5 C, 6 C, 8 C, 9 C$, respectively).

These variations of concentrations in moisture, outer layer and centre of gel were related to migrations of calcium, magnesium and inorganic phosphate ions from the centre to the outer layer during storage in ammoniacal atmosphere of model gel. Moreover, in this work, we first observed
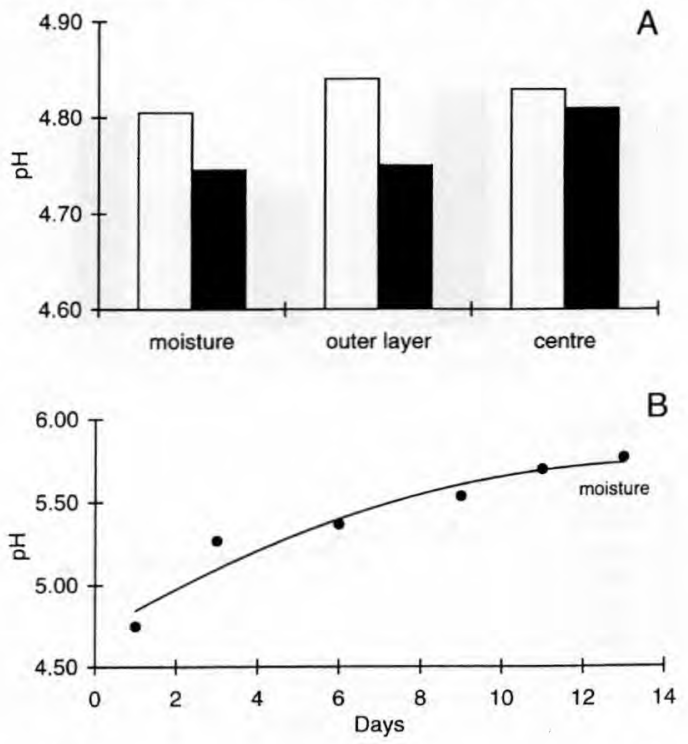

Figure 4. Evolution of $\mathrm{pH}$. Same symbols as figure 2 .

Figure 4. Évolution du $\mathrm{pH}$. Mêmes symboles que pour la figure 2 .

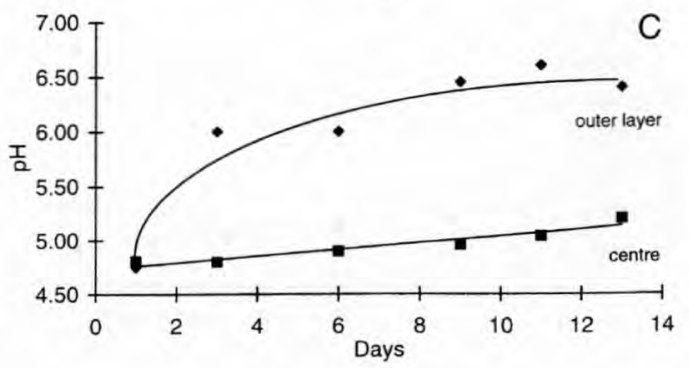


a citrate migration. However, it is probable that, in cheese, this citrate migration was not observed because of its degradation by lactic acid bacteria [4]. These phenomena of migration take place subsequent to the formation of $\mathrm{pH}$ gradient in the gel. The increase in $\mathrm{pH}$ value in the outer layer of the gel due to storage in ammoniacal atmosphere leads to the precipitation of different possible salts at the gel surface. These salts can be calcium phosphate, magnesium phosphate, calcium citrate and magnesium citrate which have low solubilities [14]. From initial composition of moisture pressed out (after brining) and with a $\mathrm{NaCl}$ concentration of $4 \mathrm{~mol} \cdot \mathrm{L}^{-1}$, theoretical calculations of calcium phosphate saturation indices in a $\mathrm{pH}$ range between 4.8 and 6.5 were carried out (figure 10). Thus, during $\mathrm{pH}$ increase, the supersaturation of calcium phosphate salts (octacalcium phosphate OCP and tricalcium phosphate TCP) increased strongly and explain the precipitation of calcium phosphate salts especially in the outer layer. Similar behaviours of both calcium phosphate salts were determined.

Evolution of calcium was similar to that obtained with magnesium because at $13 \mathrm{~d}$ of storage in an ammoniacal atmosphere, the cation concentration ratio between the outer layer and the centre was about 6 for both cations. These similar behaviours are probably due to the same low solubilities for salts of calcium and magnesium. In milk, calcium-citrate, by surpassing its solubility limit, is supersaturated and no precipitation of calcium-citrate is observed [32]. However, in our case, the citrate concentration
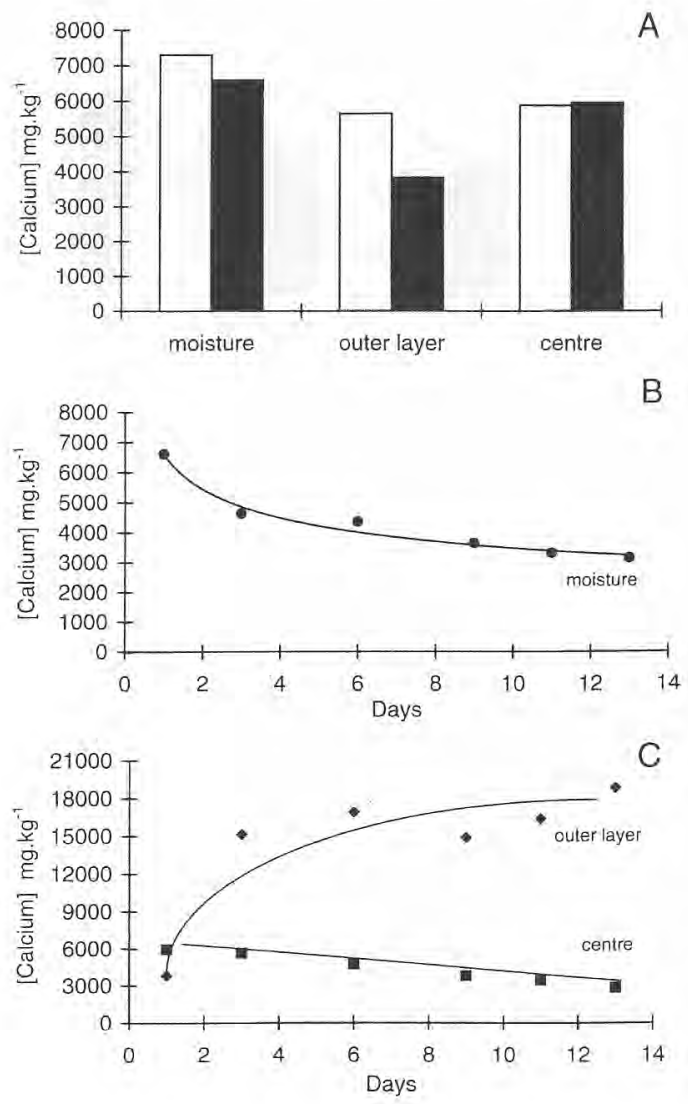

Figure 5. Evolution of calcium concentration. Same symbols as figure 2 .

Figure 5. Évolution de la concentration en calcium. Mêmes symboles que pour la figure 2. 
was higher in the aqueous phase (about $\left.3100 \mathrm{mg} \cdot \mathrm{kg}^{-1}\right)($ table I) than in milk (about $1500 \mathrm{mg} \cdot \mathrm{kg}^{-1}$ ) [32]. This high concentration of citrate was due to the release of citrate initially bound to casein (about $10 \%$ of total citrate) during the acidification of the retentate. So, these high contents in citrate and calcium contributed to a slight precipitation of calcium citrate in the outer layer. It is noteworthy that in one-month-old Cheddar cheese, Morris et al. [22] observed the presence of crystals. These authors suggested that these crystals were calcium-phosphate and calcium-citrate. On the other hand, presence of calcium and magnesium carbonate was unlikely because there is no microbial metabolism which produces $\mathrm{CO}_{2}$. In the present work, the nature of the precipitated salts was not precisely determined. However, the massic ratio $\mathrm{Ca} / \mathrm{P}$ calculated at the gel surface after $13 \mathrm{~d}$ of storage in an ammoniacal atmosphere was about 2 . This ratio suggested the presence of tricalcic phosphate (theoretical massic ratio $\mathrm{Ca} / \mathrm{P}=1.93$ ) in the outer layer of the gel. Brooker [1] identified using transmission electron microscopy, the presence of calcium phosphate in the rind of mould-ripened cheese (Coulommiers). However, this Brooker's method cannot determine the exact nature of this precipitated salt. In this sense, it would be interesting to determine the nature of precipitated salts at the cheese surface by other methods such as polarising microscopy.

Taking into account the weight of the outer layer (about $65 \mathrm{~g}$ i.e. $18 \%$ of the total weight), the $\%$ of total calcium, magnesium, inorganic phosphate and citrate present in
Figure 6. Evolution of magnesium concentration. Same symbols as figure 2.

Figure 6. Évolution de la concentration en magnésium. Mêmes symboles que pour la figure 2.
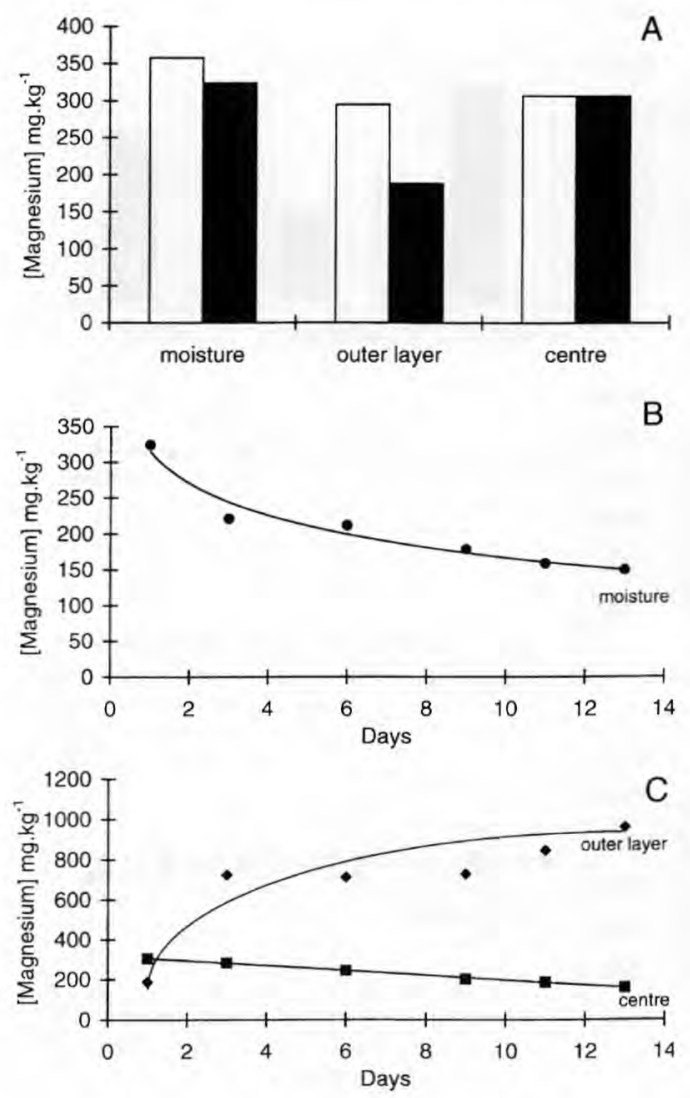
the outer layer after $13 \mathrm{~d}$ of storage in an ammoniacal atmosphere were 58, 56, 73 and $42 \%$, respectively. Precipitation of these salts in the outer layer of gel led to depletions in soluble calcium, magnesium, inorganic phosphate and citrate ion concentrations in the moisture and in the outer layer and consequently induced their migrations towards the gel surface. During their migrations, calcium, magnesium, inorganic phosphate and citrate are not dissociated in the gel. The forms of association are not determined but it is probable that soluble salts of calcium and magnesium phosphate and calcium and magnesium citrate existed.

Similar results were observed in different mould-ripened cheeses such as Camembert, Coulommiers, Brie and Pont l'Evêque [1, $15,18,19,21,25]$. In industrial cheeses, ion accumulation at the cheese surface coincides with the surface flora growth, which generates a basic $\mathrm{pH}$ at the surface of the cheese by its metabolism $[1,15,18,19,21$, 25].

\subsubsection{Sodium, chloride and potassium ions}

During storage in an ammoniacal atmosphere, the sodium, chloride and potassium concentrations in moisture increased slightly (figures $2 B, 3 B, 7 B$, respectively). In parallel, the large difference observed in sodium chloride content between the centre and the outer layer before and after brining on day 1 (figures $2 A, 3 A$, respectively) disappeared after $5 \mathrm{~d}$ of storage in an ammoniacal atmosphere because in this period, their concen-
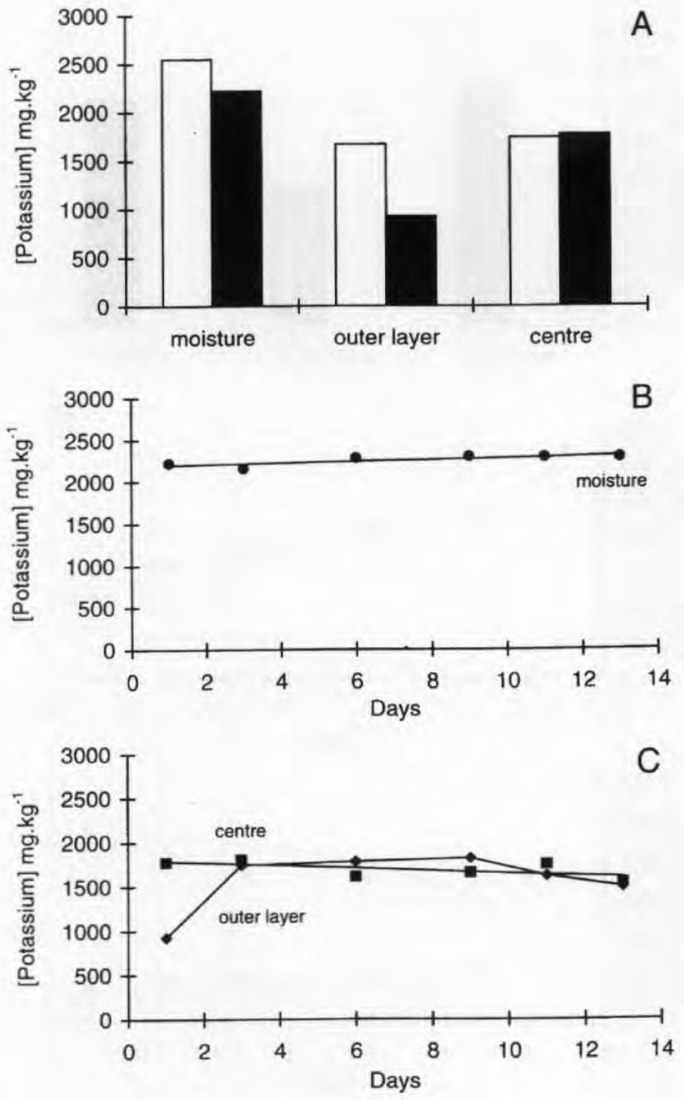

Figure 7. Evolution of potassium concentration. Same symbols as figure 2 .

Figure 7. Évolution de la concentration en potassium. Mêmes symboles que pour la figure 2. 
trations decreased in the outer layer and increased in the centre (figures $2 C, 3 C$, respectively). During this period, the sodium, potassium and chloride ions diffused in the gel matrix and at day 5 they were uniformly distributed. This time was in good accordance with a diffusion coefficient of about $0.4 \mathrm{~cm}^{2} / \mathrm{d}$ previously determined in this work for $\mathrm{NaCl}$. Then, beyond $5 \mathrm{~d}$ and up to the end of storage, the concentration of sodium and chloride in the centre increased slightly or was constant for potassium.

It is noteworthy that the storage in a non ammoniacal atmosphere gave similar results $[18,19]$ which indicated that the presence of ammonia has no influence on the diffusion of sodium, chloride and potassium. In Camembert cheese, a reversible migration of potassium in the cheese probably due to the development of surface flora was shown [19]. In our case, as the curd was poor in microorganisms due to the presence of antibiotic and fungicide, which limited their growth [17], no migration of potassium was observed.

\section{CONCLUSION}

In this study, we have prepared a model cheese through the combined use of membrane technologies and different products (lactic acid, GDL, antibiotics, fungicide). This model has been successfully used to quantify ion transfers during its brining and storage in ammoniacal atmosphere. The multiple relationships between these trans-
Figure 8. Evolution of inorganic phosphate concentration. Same symbols as figure 2 .

Figure 8. Évolution de la concentration en phosphate inorganique. Mêmes symboles que pour la figure 2 .
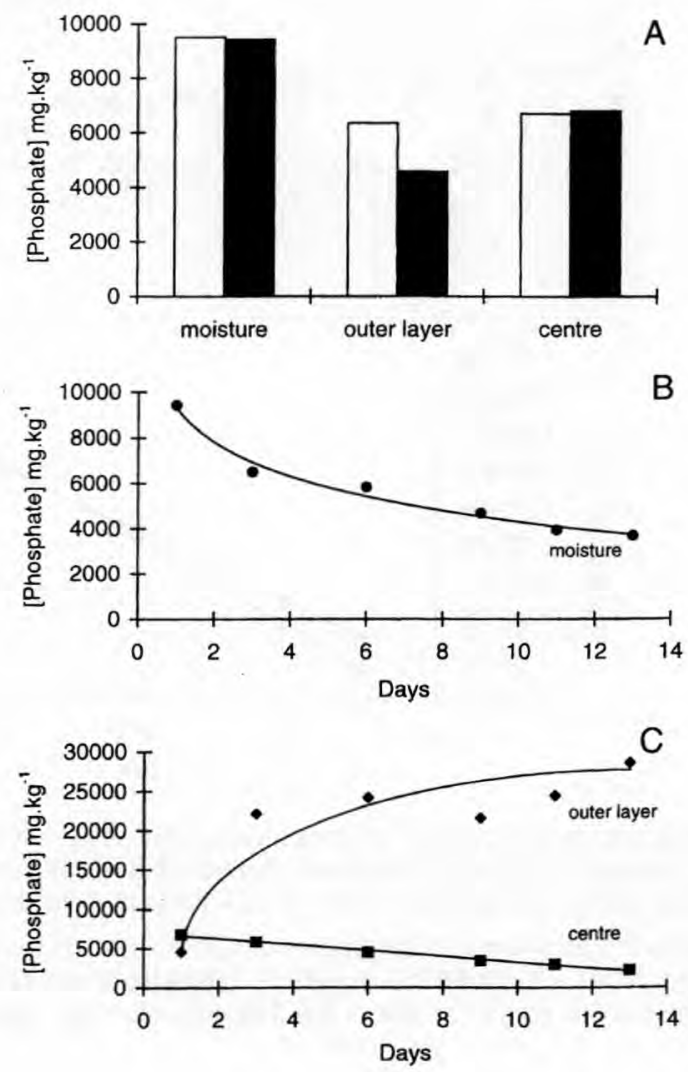

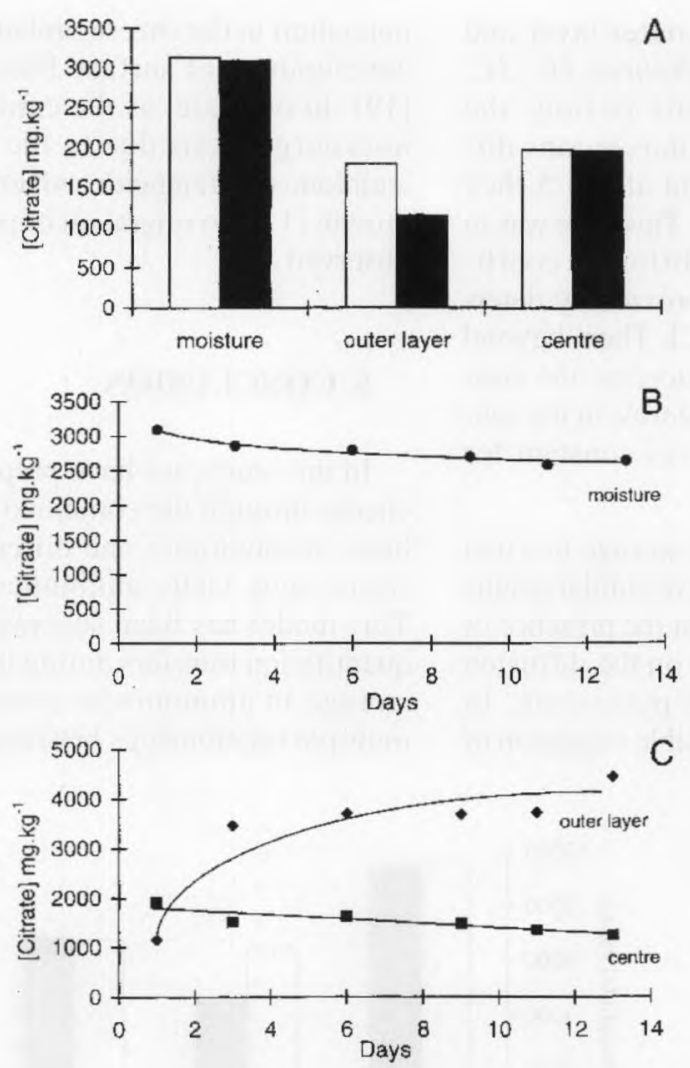

Figure 9. Evolution of citrate concentration. Same symbols as figure 2.

Figure 9. Évolution de la concentration en citrate. Mêmes symboles que pour la figure 2.

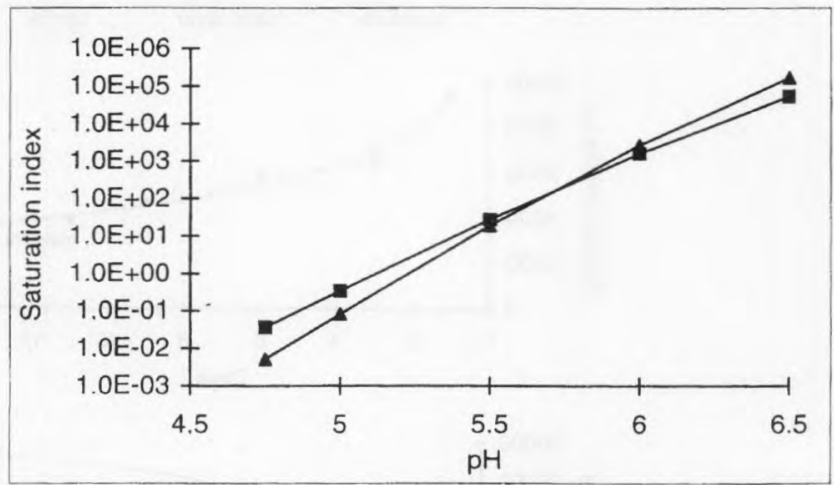

10. Theoretical saturation indices of octacalcium phosphate (OCP) $(\mathbf{\Delta})$ and tricalcium phosphate (TCP) (ם) from $\mathrm{pH} 4.8$ to 6.5 . Calculations, from the initial mineral composition of the moisture with a $\mathrm{NaCl}$ concentration of $4 \mathrm{~mol} \cdot \mathrm{L}^{-1}$, were carried out as described by Holt et al. [13].

Figure 10. Index de saturation théoriques des phosphates octacalcique (OCP) $(\boldsymbol{\Delta})$ et tricalcique (TCP) (ם) entre $\mathrm{pH} 4,8$ et $\mathrm{pH} 6,5$. Les calculs, faits à partir de la composition minérale initiale de la phase aqueuse et une concentration en $\mathrm{NaCl}$ de $4 \mathrm{~mol} \cdot \mathrm{L}^{-1}$, ont été réalisés comme décrit par Holt et al. [13]. 
fers and the physicochemical changes occurring in the model during brining and storage were not determined precisely because several factors such as $\mathrm{pH}$, structure of matrix, state of water, ionic strength, salt solubilities are involved at the same time. However, these results show that global physicochemical changes of the moisture can reflect some local changes in the cheese. Results are qualitatively in accordance with those previously described $[3,9,12,15,18$, $19,21,25,29]$ although this model has some differences in composition with industrial soft cheeses. Indeed, it contained a high concentration in gluconate and the fat content was close to zero. Moreover the initial lactose was not metabolised because it does not contain micro-organism. The potential of this model appears very interesting because it is now possible to study the influence of different factors on salt migrations. Thus, the salt migrations can be studied in gel containing more or less proteins, fat, with different casein/whey proteins ratios, with phosphopeptides or with different initial $\mathrm{pH}$ values. The brining and the ripening conditions can also be studied. The consequences of these physicochemical heterogeneities ( $\mathrm{pH}$, mineral composition) in the cheese on the texture formation can be also investigated.

\section{ACKNOWLEDGMENT}

The authors thank J.L. Maubois for critical reading of the manuscript.

\section{REFERENCES}

[1] Brooker B.E., The crystallisation of calcium phosphate at the surface of mould-ripened cheeses, Food Microstruc. 6 (1987) 25-33.

[2] Brulé G., Maubois J.L., Fauquant J., Étude de la teneur en éléments minéraux de produits obtenus. lors de l'ultrafiltration de lait sur membrane. Lait 54 (1974) 600-614.

[3] Centeleghe J.L., Millière J.B., Veillet L., Weber F., Aspects physico-chimiques et microbiologiques du salage en saumure des pâtes molles moisies, Tech. Lait. 708 (1971) 13-19.
[4] Choisy C., Desmazeaud M.J., Gripon J.C., Lamberet G., Lenoir J., Le fromage : de la science à l'assurance qualité, $3^{ }$éd., Lavoisier Tec \& Doc, Paris, 1997.

[5] Fox F.P., Proteolysis during cheese manufacture and ripening, J. Dairy Sci. 72 (1989) 1379-1400.

[6] Fox F.P., Cheese: chemistry, physics and microbiology, vol. 1, 2nd Ed,1993.

[7] Gaucheron F., Le Graët Y., Piot M., Boyaval E., Determination of anions of milk by ion chromatography, Lait 76 (1996) 433-443.

[8] Geurts T.J., Walstra P., Mulder H., Brine composition and the prevention of the defect "soft rind" in cheese, Neth. Milk Dairy J. 26 (1972) 168-172.

[9] Geurts T.J., Walstra P., Mulder H., Transport of salt and water during salting of cheese. 1. Analysis of the processes involved, Neth. Milk Dairy J. 28 (1974) 102-129.

[10] Geurts T.J., Walstra $P_{+}$, Mulder H., Transport of salt and water during salting of cheese 2. Quantities of salt taken up and of moisture lost, Neth. Milk Dairy J. 34 (1980) 229-254.

[11] Grappin R., Rank T.C., Olson F., Primary proteolysis of cheese proteins during ripening. A review, J. Dairy Sci. 68 (1985) 531-540.

[12] Hardy J., Étude de la diffusion de sel dans les fromages à pâte molle type Camembert. Comparaison du salage à sec et du salage en saumure, thèse $\mathrm{D}^{\mathrm{r}}$-ingénieur, université Nancy-I, 1976.

[13] Holt C., Dalgleish D.G., Jenness R., Calculation of the ion equilibria in milk diffusate and comparison with experiment, Anal. Biochem. 113 (1981) 154-163.

[14] Holt C., Effect of heating and cooling on the milk salts and their interaction with casein, Special issue: Heat-induced changes in milk, Bull. Int. Dairy Fed. 9501, 2nd ed. (1995) 105-133.

[15] Karahadian C., Lindsay R.C., Integrated roles of lactate, ammonia, and calcium in texture development in mold surface-ripened cheese, J. Dairy Sci. 70 (1987) 909-918.

[16] Lawrence R.C., Creamer L.K., Gilles J., Texture development during cheese ripening, J. Dairy Sci. 70 (1987) 1748-1760.

[17] Le Bars D., Desmazeaud M.J., Gripon J.C., Bergère J.L., Êtude du rôle des microorganismes et de leurs enzymes dans la maturation des fromages. I. Fabrication aseptique d'un caillé modèle, Lait 55 (1975) 377-389.

[18] Le Graët Y., Lepienne A., Brulé G., Ducruet P., Migration du calcium et des phosphates inorganiques dans les fromages à pâte molle de type Camembert au cours de I'affinage, Lait 63 (1983) 317-332.

[19] Le Graët Y., Brulé G., Migration des macro et oligo-éléments dans un fromage à pâte molle de type Camembert, Lait 68 (1988) 219-234. 
[20] Maubois J.L., Mocquot G., Préparation de fromage à partir de « préfromage liquide » obtenu par ultrafiltration du lait, Lait 51 (1971) 495-533.

[21] Metche M., Fanni J., Rôle de la flore fongique dans l'accumulation du calcium et du phosphore à la surface des fromages type Camembert, Lait 58 (1978) 337-354.

[22] Morris H.A., Holt C., Brooker B.E., Banks J.M., Manson W., Inorganic constituents of cheese: analysis of juice from a one-month-old Cheddar cheese and the use of light and electron microscopy to characterize the crystalline phases, J. Dairy Res. 55 (1988) 255-268.

[23] Mpagana M., Hardy J., Effect of salting on some rheological properties of fresh Camembert cheese as measured by uniaxial compression, Milchwissenschaft 41 (1986) 210-213.

[24] Noomen A., The role of the surface flora in the softening of cheeses with a low initial $\mathrm{pH}$, Neth. Milk Dairy J. 37 (1983) 229-232.

[25] Oumer A., Dynamique d'évolution des flores microbiennes d'un fromage à pâte molle et à croûte lavée en relation avec quelques aspects physico-chimiques et biochimiques, thèse doctorat Institut national agronomique Paris-Grignon, 1997.

[26] Pierre A., Michel F., Le Graët Y., Berrier J., Soft goat cheeses at different ripening stages: cheese structure, composition and non solvent water, Lait 79 (1999) 489-501.

[27] Salvat-Brunaud D., Maubois J.L., Le Graët Y., Piot M., Maillard M.B., Corre C., Thierry A., Extraction et analyse de la phase aqueuse de l'emmental à 4 stades d'affinage, Lait 75 (1995) 239-249.

[28] Solorza F.J., Bell A.E., The effect of calcium addition on the rheological properties of a soft cheese at various stages of manufacture, Int. J. Dairy Technol. 51 (1998) 23-29.

[29] Terré E., Le Graët Y., Brulé G., Maubois J.L., Étude du transfert des solutés des fromages à pâte molle dans les saumures. Intérêt du traitement par ultrafiltration sur membrane, Tech. Lait. 997 (1985) 39-47.

[30] Trouvé E., Maubois J.L., Piot M., Madec M.N., Fauquant J., Rouault A., Tabard J., Brinckman G., Rétention de différentes espèces microbiennes lors de l'épuration du lait par microfiltration en flux tangentiel, Lait 71 (1991) 1-13.

[31] Vassal L., Monnet V., Le Bars D., Roux C., Gripon J.C., Relation entre le $\mathrm{pH}$, la composition chimique et la texture des fromages de type Camembert, Lait 66 (1986) 341-351.

[32] Walstra P., Jenness R., Dairy Chemistry and Physics, John Wiley and sons, New York (1984) 